\title{
EFEKTIVITAS KUNYIT (Curcuma domestica) SEBAGAI PEREDUKSI FORMALIN PADA TAHU
}

\author{
Zainal Berlian ${ }^{1)}$, Elfira Rosa Pane ${ }^{2)}$, Sri Hartati ${ }^{3)^{*}}$ \\ ${ }^{1), 2)}$ Dosen Biologi, Fakultas Tarbiyah dan Keguruan, UIN Raden Fatah Palembang \\ ${ }^{1}$ Mahasiswa Pendididkan Biologi, Fakultas Tarbiyah dan Keguruan, UIN Raden Fatah \\ Palembang
}

*Email: srihartati0301@gmail.com

\begin{abstract}
The use of formalin increasingly widely circulated among sellers tahu, because nature tahu easily broken then the sellers know much use out using formalin. Turmeric has active compounds that is saponin. It can be used to minimize the presence of formaldehyde in tahu This study used tahu immersed in $5 \%$ formalin solution added a solution of turmeric. The research carried on in the Laboratory of the Polytechnic Palembang Health Nutrition Department. Determination of formaldehyde using a spectrophotometer test. The study used a completely randomized design (CRD) with a model of Factorial three factors, namely soaking treatment (60 minutes, 75 minutes, 90 minutes) giving a solution of Turmeric $(0 \%, 10 \%, 15$ $\%, 20 \%)$ and storage factor $(0,24,48,72$ hours $)$. The parameters used are formaldehyde levels and organoleptic test. These results indicate that treatment of soaking time did not significantly affect the levels of formaldehyde in tahu that F count -0.022 smaller than $\mathrm{F}$ table 6.94. Treatment addition of turmeric solution concentration does not significantly affect the levels of formaldehyde at 0.864 tahu that $\mathrm{F}$ count is smaller than $\mathrm{F}$ table 3.16. The storage time treatment also did not significantly affect the levels of formaldehyde in tahu that $\mathrm{F}$ count -11.16 smaller than 2.73. However, the interaction between the immersion treatment, turmeric solution concentration and storage time significantly affect the levels of formaldehyde in the tahu, namely $282.16 \mathrm{~F}$ count larger than F table 1.75 . And the results of organoleptic able to change the texture of aroma and color in tahu with decreasing levels of formaldehyde in tahu. In this study, formaldehyde levels lowest in 90 minutes soaking treatment, the concentration of $20 \%$ deposit 72 hours .
\end{abstract}

Keywords : Formalin; Tahu; Turmeric

\section{PENDAHULUAN}

Tahu merupakan produk makanan yang berasal dari olahan kedelai yang relatif murah, praktis dan mudah didapat. Produk pangan hasil olahan kedelai ini memiliki sifat bahan pangan yang cepat mengalami kerusakan sehingga dapat digolongkan ke dalam golongan high perishable food (Shurtleff \& Aoyagi 1979"dalam"Mustofa, 
2006). Tahu hanya bertahan selama kurang lebih tiga hari tanpa menggunakan bahan pengawet, walaupun disimpan pada suhu rendah, yaitu suhu maksimum $15^{\circ} \mathrm{C}$ (Fardiaz 1983"dalam"Mustofa, 2006). Komposisi tahu yang banyak mengandung protein dan air menyebabkan tahu merupakan media yang cocok untuk tumbuhnya mikroba, sehingga tahu menjadi cepat mengalami kerusakan (Sarwono \& Saragih 2003 "dalam" Mustofa, 2006). Kerusakan mikrobiologis pada tahu tergantung dari beberapa faktor, antara lain (1) adanya bakteri yang tahan panas seperti golongan pembentuk spora dan termodurik, (2) adanya bakteri kontaminan yang mengkontaminasi tahu selama proses pembuatan sampai tahu siap untuk dikonsumsi, (3) suhu penyimpanan, dan (4) adanya enzim tahan panas yang dihasilkan oleh golongan bakteri tertentu (Shurtleff \& Aoyagi 1979 "dalam" Mustofa, 2006).

Perubahan yang dapat terlihat dari luar apabila telah mengalami kerusakan, adalah mengeluarkan aroma asam sampai busuk, permukaan tahu berlendir, tekstur menjadi lunak, kekompakkan berkurang, warna dan penampakkan tidak cerah, kadang-kadang berjamur pada permukaannya (Fardiaz, 1988 "dalam" Damayanti, 2014). Mengingat tahu sebagai salah satu produk makanan yang memiliki sifat mudah rusak (highly perishable), maka penanganan dan proses produksi yang baik mutlak diperlukan agar mutu dan keamanan tahu tetap segar pada saat dikonsumsi. Mutu tahu terutama ditentukan oleh keadaan fisik, organoleptik (warna, aroma dan tekstur).

Dewasa ini, penggunaan formalin marak di kalangan penjual tahu, karena formalin dianggap paling efektif untuk mengawetkan makanan seperti tahu. Pada akhir tahun 2005 dan awal tahun 2006 publikasi tentang penyalahgunaan formalin pada bahan makanan termasuk tahu sangat gencar pada media masa di Indonesia. Dari hasil sampling laboratorium di beberapa kota besar di Indonesia diketahui bahwa sebesar $1,91 \%$ tahu mengandung formalin dengan persentase terbesar pada Kotamadya Kediri yaitu 10,42\%. Penelitian yang telah dilakukan oleh Restu (2011) menyebutkan bahwa banyak sekali bahan pangan yang beredar di masyarakat yang menggunakan bahan pengawet dengan tujuan untuk memperpanjang masa simpannya, seperti bakso, tahu, mi basah, dan ikan kering. Ciri-ciri tahu yang mengandung formalin adalah tahu tidak rusak sampai tiga hari pada suhu ruang dan bertahan lebih dari 15 hari pada suhu dingin, tahu keras namun tidak padat, dan baunya agak menyengat khas formalin (Mujadjanto 2005 "dalam" Mustofa, 2006).

Pemakaian formalin di dalam makanan sangat tidak dianjurkan karena dalam formalin terkandung zat formaldehid yang di dalam tubuh bersifat racun. Kandungan formalin yang tinggi di dalam tubuh akan menyebabkan iritasi lambung, alergi, bersifat karsinogenik dan bersifat mutagen serta orang yang mengkonsumsinya akan mengalami muntah, diare dan kencing bercampur darah, serta apabila terhirup akan merangsang terjadinya iritasi hidung, tenggorokan dan mata (Winarno, 2004 "dalam" Damayanti, 2014). Penggunaan formalin yang berbahaya nampaknya belum disadari betul di kalangan masyarakat. Ambang batas aman formalin di dalam tubuh menurut International Programme on Chemical Safety (IPCS), yaitu lembaga 
khusus PBB yang bertugas mengontrol keselamatan penggunaan bahan kimiawi, dalam bentuk cairan adalah 1 miligram per liter, sedangkan dalam bentuk makanan untuk orang dewasa adalah 1,5 - 14mg/hari (Wisnu, 2006; Nurheti, 2007).

Suntoro (1983) dalam Damayanti (2014), menyatakan bahwa formalin merupakan senyawa aktif yang dapat berikatan dengan bahan makanan seperti protein, lemak dan karbohidrat. Formalin merupakan larutan formaldehid dalam air. Ikatan antara formaldehid dan protein, diantaranya membentuk ikatan silang yang sulit dipecah (Marquie, 2001 "dalam" Damayanti, 2014). Oleh karena itu, dibutuhkan upaya untuk merubah ikatan struktur kimia bahan makanan, sehingga kandungan formalin dapat berkurang dan layak untuk dikonsumsi manusia. Salah satunya dengan memanfaatkan zat aktif yang ada pada kunyit yang mengandung senyawa saponin.

Larutan kunyit memiliki senyawa aktif yang dapat digunakan untuk meminimalisir keberadaan formalin yaitu saponin (Damayanti, 2014). Ada banyak data dan literatur yang membuktikan bahwa rimpang kunyit berpotensi besar dalam aktifitas farmakologi yaitu sebagai anti inflamasi, anti imunodefisiensi, anti virus, anti bakteri, anti jamur, anti oksidan, anti karsinogenik, dan anti infeksi (Kristina et.al, 2007 “dalam” Damayanti, 2014). Sedangkan pada kunyit, senyawa bioaktif yang berperan sebagai antimikroba adalah kurkumin, desmetoksikumin dan bidestometoksikumin dimana di dalamnya terdapat saponin yang terkandung surfaktan yang berfungsi sebagai emulgator (Purwani dan Muwakhidah, 2008 "dalam" Damayanti, 2014).
Hal ini sesuai dengan pendapat Gunawan (2004) dalam Damayanti (2014), saponin adalah suatu glikosida yang mungkin ada pada banyak macam tumbuhan. Saponin terdiri dari sapogenin yaitu bagian yang bebas dari glikosida yang disebut juga "aglycone" dan sapogenin yang mengikat sakarida. Karena sapogenin bersifat lipofilik serta sakarida bersifat hidrofilik maka saponin bersifat amfifilik (amphipilic atau surfactant properties). Surfactan adalah senyawa aktif permukaan yang dapat menurunkan tegangan permukaan sekaligus memiliki gugus hidrofilik dan hidrofobik dalam satu struktur molekul. Sifat tersebut menyebabkan surfaktan memiliki potensi sebagai komponen bahan adesif, bahan penggumpal, pembusa dan pengemulasi (Jhonson \& Fritz, 1989 "dalam" Damayanti, 2014).

Pada penelitian sebelumnya oleh Sihombing, P. A (2007) menunjukan hasil bahwa kunyit dapat menjadi pengawet alami karena memiliki senyawa antimikroba, selanjutnya penelitian yang dilakukan oleh Damayanti, E (2014) menunjukan hasil bahwa kunyit mampu mereduksi formalin pada udang karena kunyit mampu meminimalisir keberadaan formalin pada udang.

Adapun makanan yang baik yaitu makanan yang dapat dipertimbangkan dengan akal, dan ukurannya adalah kesehatan. Artinya makanan yang baik adalah yang berguna dan tidak membahayakan bagi tubuh manusia dilihat dari sudut kesehatan. Makanan yang baik belum tentu halal dan yang halal belum tentu baik.

Dalam Al-Quran surah Al Baqarah: 172 menjelaskan bahwa : 


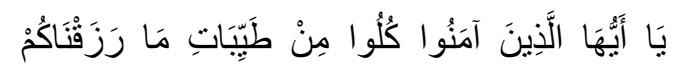

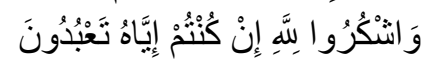

Artinya : "Hai orang-orang yang beriman, makanlah diantara rezeki yang baik-baik yang Kami berikan kepadamu dan bersyukurlah kepada Allah, jika benarbenar hanya kepada-Nya kamu menyembah.

Di dalam ayat ini, Allah mengulangi kembali agar memakan makanan yang baik, sebagaimana yang ditegaskan dalam ayat 168. Selanjutnya Allah menyeru agar selalu bersyukur terhadap nikmat-Nya jika benarbenar beribadah dan menghamba kepadaNya.

\section{METODOLOGI PENELITIAN}

Penelitian ini merupakan penelitian deskriptif eksperimen laboratorium dengan rancangan acak lengkap. Rancangan percobaan yang digunakan Rancangan Acak Lengkap (RAL) dengan 3 perlakuan dan 3 ulangan yaitu: perlakuan perendaman selama (60 menit, 75 menit, 90 menit), pemberian larutan kunyit (0\%), (10\%), (15\%), (20\%) dan perlakuan penyimpanan (0, 24 jam, 48 jam, 72 jam) parameter yang digunakan adalah uji kadar formalin dan uji organoleptik.

\section{Waktu dan Tempat Penelitian}

Penelitian ini dilakukan di Laboratorium Analisis Kesehatan Gizi Palembang, tanggal 9-13 November 2015.

\section{Alat dan Bahan Penelitian}

Alat yang digunakan untuk praktikum ini yaitu beaker glass, pengaduk, kompor, Bahan kimia yang dipakai adalah asam kromatofat, Aquadest, $\mathrm{H}_{2} \mathrm{PO}_{4}, \mathrm{H}_{2} \mathrm{SO}_{4}$ tabung reaksi, erlenmeyer, baskom, mortal \& alu, pipet Gondok, pipet tetes, gelas ukur, hot plate, spatula, neraca analitik, spektrofotometer. Bahan yang dipakai pada penelitian ini adalah tahu berformalin.

\section{PROSEDUR KERJA}

\section{Pembuatan larutan formalin}

1) Pada tahap ini dilakukan pembuatan larutan formalin $5 \%$

2) Larutan formalin $37 \%$ diencerkan menjadi $5 \%$ menggunakan rumus $\mathrm{V}_{1} \mathrm{M}_{1}=\mathrm{V}_{2} \mathrm{M}_{2}$ dan didapati hasil larutan formalin sebanyak $135 \mathrm{ml}$.

\section{Pembuatan Larutan Kunyit}

1) Larutan kunyit dibuat berbagai konsentrasi $(0 \%, 10 \%, 15 \%, 20 \%)$ dengan ditambahkan aquadest.

2) Pembuatan larutan kunyit dengan jumlah gram zat dalam $1000 \mathrm{ml}$ pelarut (aquades)

3) Untuk konsentrasi $0 \%$ tidak ditambahkan larutan kunyit, konsentrasi $10 \%$ dengan menimbang kunyit sebanyak 100 gr dengan penambahan aquades sebanyak $900 \mathrm{ml}$, begitu pula untuk larutan konsentrasi $15 \%$ dengan menimbang kunyit sebanyak 150 gr ditambahkan aquades sebanyak $850 \mathrm{ml}$, dan untuk konsentrasi $20 \%$ dengan menimbang kunyit sebanyak 200 gr ditambahkan aquades sebanyak $800 \mathrm{ml}$.

4) Selanjutnya tahu berformalin direndam dalam larutan kunyit selama 60 menit 75 menit dan 95 menit.

5) Setelah tahu direndam, selanjutnya dilakukan uji kadar formalin dengan menggunakan uji kuantitatif untuk mengetahui kadar formalin setelah perendaman dengan larutan kunyit dengan menggunakan spektrofotometer

\section{Uji kadar formalin}

Pengujian secara kuantitatif (Hastuti, 2010):

1) Pembuatan larutan standar, formalin $37 \%$ diambil sebanyak $0,027 \mathrm{ml}$, 
tambahakan tambahakan aquadest sebanyak $500 \mathrm{ml}$ atau $20 \mathrm{ppm}$, buat konsentrasi yang berbeda yaitu $0 \mathrm{M}$; $0,05 \mathrm{M} ; 0,1 \mathrm{M} ; 0,5 \mathrm{M} ; 0,75 \mathrm{M} ; 1,0 \mathrm{M}$; $1,5 \mathrm{M}$; dan $2 \mathrm{M}$

2) Kemudian dimasukkan ke dalam tabung reaksi yang sudah diberi label (8 tabung reaksi),

3) Asam kromatofat ditambahkan sebanyak $5 \mathrm{ml}$ pada tiap konsentrasi yang berbeda, lalu tabung reaksi dipanaskan selama 30 menit dengan kompor pada suhu 1000C, sehingga terbentuklah larutan standar

4) Selanjutnya adalah pembuatan larutan uji, sampel sebanyak $20 \mathrm{ml}$ dihomogenkan dengan aquadest, sampel yang telah diuji dipanaskan dengan kompor sampai mendidih, kemudian dilakukan penyaringan dan pendinginan.

5) Selanjutnya sampel diambil sebanyak 2 $\mathrm{ml}$ dan dimasukkan ke dalam tabung reaksi dengan 3 kali ulangan. Tambahkan asam kromatofat sebanyak $5 \mathrm{ml}$ pada masing-masing tabung reaksi. Panaskan selama 20 menit lalu dinginkan

6) Ukur absorbance dengan spektrofotometer dengan panjang gelombang $520 \mathrm{~nm}$.

7) Selanjutnya tahu yang diberi formalin dan diberi larutan kunyit, kemudian disimpan pada suhu dingin selama 24 jam, 48 jam, dan 72 jam. Selanjutnya dilakukan kembali uji kadar formalin selama penyimpan.

\section{HASIL DAN PEMBAHASAN}

Hasil Penelitian Uji Kandungan Formalin Secara Kuantitatif

Tabel 1. Data Hasil Uji Kadar Formalin pada Tahu Tanpa Penyimpanan dan Perendaman 60 menit

\begin{tabular}{cccccccc}
\hline Penyimpanan & Perendaman & Sampel & \multicolumn{3}{c}{ Ulangan } & Total & $\begin{array}{c}\text { Rata- } \\
\text { Rata }\end{array}$ \\
& & & $\mathbf{1}$ & $\mathbf{2}$ & $\mathbf{3}$ & & 1,612 \\
Ho & & Tahu Kontrol & 1,612 & 1,611 & 1,612 & 4,835 & 1,524 \\
Tanpa & \multirow{2}{*}{60 menit } & $10 \%$ & 1,524 & 1,523 & 1,524 & 4,571 & 1,524 \\
Penyimpanan & & $15 \%$ & 1,093 & 1,093 & 1,091 & 3,277 & 1,092 \\
& & $20 \%$ & 0,603 & 0,601 & 0,602 & 1,806 & 0,602 \\
\hline
\end{tabular}

Tabel 2. Data Hasil Uji kadar Formalin pada Tahu Tanpa Penyimpanan dan Perendaman 75 Menit

\begin{tabular}{cccccccc}
\hline Penyimpanan & \multirow{2}{*}{ Perendaman } & Sampel & $\mathbf{1}$ & $\mathbf{2}$ & $\mathbf{3}$ & Total & $\begin{array}{c}\text { Rata- } \\
\text { Rata }\end{array}$ \\
& & Tahu Kontrol & 1,612 & 1,611 & 1,612 & 4,835 & 1,612 \\
H0 & \multirow{2}{*}{75 menit } & $10 \%$ & 1,522 & 1,522 & 1,523 & 4,567 & 1,522 \\
Tanpa & $15 \%$ & 1,087 & 1,084 & 1,087 & 3,258 & 1,086 \\
Penyimpanan & & $20 \%$ & 0,599 & 0,599 & 0,598 & 1,796 & 0,599 \\
\hline
\end{tabular}


Tabel 3. Data Hasil Uji kadar Formalin pada Tahu Tanpa Penyimpanan dan Perendaman 90 Menit

\begin{tabular}{cccccccc}
\hline \multirow{2}{*}{ Penyimpanan } & \multirow{2}{*}{ Perendaman } & \multirow{2}{*}{ Sampel } & $\mathbf{1}$ & $\mathbf{2}$ & $\mathbf{3}$ & Total & $\begin{array}{c}\text { Rata- } \\
\text { Rata }\end{array}$ \\
\hline \multirow{3}{*}{ H0 } & & Tahu Kontrol & 1,612 & 1,611 & 1,612 & 4,835 & 1,612 \\
Tanpa & \multirow{2}{*}{90 menit } & $10 \%$ & 1,519 & 1,516 & 1,516 & 4,551 & 1,517 \\
Penyimpanan & & $15 \%$ & 1,083 & 1,081 & 1,081 & 3,245 & 1,082 \\
& & $20 \%$ & 0,593 & 0,591 & 0,593 & 1,777 & 0,592 \\
\hline
\end{tabular}

Tabel 4. Data Hasil Uji kadar Formalin pada Tahu Penyimpanan 24 Jam dan Perendaman 60 Menit

\begin{tabular}{cccccccc}
\hline \multirow{2}{*}{ Penyimpanan } & \multirow{2}{*}{ Perendaman } & Sampel & \multicolumn{3}{c}{ Ulangan } & Total & $\begin{array}{c}\text { Rata- } \\
\text { Rata }\end{array}$ \\
& & & $\mathbf{1}$ & $\mathbf{2}$ & $\mathbf{3}$ & & \\
\hline \multirow{2}{*}{ 24 Jam } & & Tahu Kontrol & 1,568 & 1,566 & 1,568 & 4,702 & 1,567 \\
Penyimpanan & \multirow{2}{*}{60 menit } & $10 \%$ & 1,462 & 1,463 & 1,463 & 4,388 & 1,463 \\
& & $15 \%$ & 0,619 & 0,622 & 0,620 & 1,861 & 0,620 \\
& & $20 \%$ & 0,597 & 0,597 & 0,596 & 1,790 & 0,597 \\
\hline
\end{tabular}

Tabel 5. Data Hasil Uji kadar Formalin pada Tahu Penyimpanan 24 Jam dan Perendaman 75 Menit

\begin{tabular}{cccccccc}
\hline \multirow{2}{*}{ Penyimpanan } & \multirow{2}{*}{ Perendaman } & Sampel & $\mathbf{1}$ & $\mathbf{2}$ & $\mathbf{3}$ & Total & $\begin{array}{c}\text { Rata- } \\
\text { Rata }\end{array}$ \\
\cline { 3 - 7 } & & Tahu Kontrol & 1,568 & 1,566 & 1,568 & 4,702 & 1,567 \\
24 Jam & \multirow{2}{*}{ Penyimpanan } & \multirow{2}{*}{$75 \%$} & 1,457 & 1,456 & 1,457 & 4,370 & 1,457 \\
& & $15 \%$ & 0,618 & 0,617 & 0,616 & 1,851 & 0,617 \\
& & $20 \%$ & 0,594 & 0,593 & 0,591 & 1,778 & 0,593 \\
\cline { 3 - 7 }
\end{tabular}

Tabel 6. Data Hasil Uji kadar Formalin pada Tahu Penyimpanan 24 Jam dan Perendaman 90 Menit

\begin{tabular}{cccccccc}
\hline Penyimpanan & \multirow{2}{*}{ Perendaman } & Sampel & $\mathbf{1}$ & $\mathbf{2}$ & $\mathbf{3}$ & Total & $\begin{array}{c}\text { Rata- } \\
\text { Rata }\end{array}$ \\
& & Tahu Kontrol & 1,568 & 1,566 & 1,568 & 4,702 & 1,567 \\
\multirow{2}{*}{ 24 Jam } & \multirow{2}{*}{90 menit } & $10 \%$ & 1,445 & 1,444 & 1,444 & 4,333 & 1,444 \\
Penyimpanan & & $15 \%$ & 0,614 & 0,612 & 0,611 & 1,837 & 0,612 \\
& & $20 \%$ & 0,585 & 0,582 & 0,582 & 1,749 & 0,583 \\
\hline
\end{tabular}

Tabel 7. Data Hasil Uji kadar Formalin pada Tahu Penyimpanan 48 Jam dan Perendaman 60 Menit

\begin{tabular}{cccccccc}
\hline Penyimpanan & Perendaman & Sampel & \multicolumn{3}{c}{ Ulangan } & Total & $\begin{array}{c}\text { Rata- } \\
\text { Rata }\end{array}$ \\
& & & $\mathbf{1}$ & $\mathbf{2}$ & $\mathbf{3}$ & & 1,542 \\
\hline \multirow{2}{*}{ 48 Jam } & & Tahu Kontrol & 1,542 & 1,542 & 1,541 & 4,625 & 1,542 \\
Penyimpanan & \multirow{2}{*}{60 menit } & $10 \%$ & 1,361 & 1,358 & 1,361 & 4,080 & 1,360 \\
& & $15 \%$ & 0,611 & 0,609 & 0,607 & 1,827 & 0,609 \\
& & $20 \%$ & 0,591 & 0,589 & 0,589 & 1,769 & 0,590 \\
\hline
\end{tabular}


Tabel 8. Data Hasil Uji kadar Formalin pada Tahu Penyimpanan 48 Jam dan Perendaman 75 Menit

\begin{tabular}{|c|c|c|c|c|c|c|c|}
\hline \multirow{2}{*}{ Penyimpanan } & \multirow{2}{*}{ Perendaman } & \multirow{2}{*}{ Sampel } & \multicolumn{3}{|c|}{ Ulangan } & \multirow{2}{*}{ Total } & \multirow{2}{*}{$\begin{array}{l}\text { Rata- } \\
\text { Rata }\end{array}$} \\
\hline & & & 1 & 2 & 3 & & \\
\hline & & Tahu Kontrol & 1,542 & 1,542 & 1,541 & 4,625 & 1,542 \\
\hline 48 Jam & & $10 \%$ & 1,355 & 1,354 & 1,356 & 4,065 & 1,355 \\
\hline \multirow[t]{2}{*}{ Penyimpanan } & 75 menit & $15 \%$ & 0,605 & 0,603 & 0,602 & 1,810 & 0,603 \\
\hline & & $20 \%$ & 0,588 & 0,582 & 0,585 & 1,755 & 0,587 \\
\hline
\end{tabular}

Tabel 9. Data Hasil Uji kadar Formalin pada Tahu Penyimpanan 48 Jam dan Perendaman 90 Menit

\begin{tabular}{cccccccc}
\hline Penyimpanan & \multirow{2}{*}{ Perendaman } & Sampel & $\mathbf{1}$ & $\mathbf{2}$ & $\mathbf{3}$ & Total & $\begin{array}{c}\text { Rata- } \\
\text { Rata }\end{array}$ \\
& & Tahu Kontrol & 1,542 & 1,542 & 1,541 & 4,625 & 1,542 \\
48 Jam & \multirow{2}{*}{90 menit } & $10 \%$ & 1,345 & 1,344 & 1,344 & 4,033 & 1,344 \\
Penyimpanan & & $15 \%$ & 0,598 & 0,596 & 0,596 & 1,790 & 0,597 \\
& & $20 \%$ & 0,580 & 0,576 & 0,579 & 1,735 & 0,578 \\
\hline
\end{tabular}

Tabel 10. Data Hasil Uji kadar Formalin pada Tahu Penyimpanan 72 Jam dan Perendaman 60 Menit

\begin{tabular}{cccccccc}
\hline Penyimpanan & \multirow{2}{*}{ Perendaman } & Sampel & $\mathbf{1}$ & $\mathbf{2}$ & $\mathbf{3}$ & Total & $\begin{array}{c}\text { Rata- } \\
\text { Rata }\end{array}$ \\
& & Tahu Kontrol & 1,527 & 1,525 & 1,525 & 4,577 & 1,562 \\
72 Jam & \multirow{2}{*}{60 menit } & $10 \%$ & 1,095 & 1,092 & 1,094 & 3,281 & 1,094 \\
Penyimpanan & $15 \%$ & 0,605 & 0,604 & 0,604 & 1,813 & 0,604 \\
& & $20 \%$ & 0,587 & 0,585 & 0,586 & 1,758 & 0,586 \\
\hline
\end{tabular}

Tabel 11. Data Hasil Uji kadar Formalin pada Tahu Penyimpanan 72 Jam dan Perendaman 75 Menit

\begin{tabular}{|c|c|c|c|c|c|c|c|}
\hline \multirow{2}{*}{ Penyimpanan } & \multirow{2}{*}{ Perendaman } & \multirow{2}{*}{ Sampel } & \multicolumn{3}{|c|}{ Ulangan } & \multirow{2}{*}{ Total } & \multirow{2}{*}{$\begin{array}{l}\text { Rata- } \\
\text { Rata }\end{array}$} \\
\hline & & & 1 & 2 & 3 & & \\
\hline & & Tahu Kontrol & 1,527 & 1,525 & 1,525 & 4,577 & 1,526 \\
\hline 72 Jam & & $10 \%$ & 1,091 & 1,089 & 1,090 & 3,27 & 1,090 \\
\hline \multirow{2}{*}{ Penyimpanan } & 75 menit & $15 \%$ & 0,604 & 0,598 & 0,597 & 1,799 & 0,599 \\
\hline & & $20 \%$ & 0,583 & 0,581 & 0,582 & 1,746 & 0,582 \\
\hline
\end{tabular}

Tabel 12. Data Hasil Uji kadar Formalin pada Tahu Penyimpanan 72 Jam dan Perendaman 90 Menit

\begin{tabular}{cccccccc}
\hline Penyimpanan & \multirow{2}{*}{ Perendaman } & Sampel & $\mathbf{1}$ & $\mathbf{2}$ & $\mathbf{3}$ & Total & $\begin{array}{c}\text { Rata- } \\
\text { Rata }\end{array}$ \\
& & Tahu Kontrol & 1,527 & 1,525 & 1,525 & 4,566 & 1,526 \\
72 Jam & \multirow{2}{*}{90 menit } & $10 \%$ & 1,083 & 1,081 & 1,081 & 3,245 & 1,082 \\
Penyimpanan & & $15 \%$ & 0,596 & 0,594 & 0,593 & 1,783 & 0,594 \\
& & $20 \%$ & 0,569 & 0,568 & 0,568 & 1,705 & 0,568 \\
\hline
\end{tabular}


Hasil pengamatan yang telah diperoleh, kemudian dilakukan analisa sidik ragam anova dengan 48 perlakuan dan 3 ulangan.
Adapun hasil analisis tersebut adalah sebagai berikut :

Tabel 13. Hasil Uji Organoleptik Panelis

\begin{tabular}{|c|c|c|c|c|c|}
\hline \multirow[b]{2}{*}{ No } & \multirow[b]{2}{*}{ Aspek Penilaian } & \multirow[b]{2}{*}{$\begin{array}{c}\text { Tahu } \\
\text { Kontrol }\end{array}$} & \multicolumn{3}{|c|}{ Perlakuan Sampel } \\
\hline & & & $10 \%$ & $15 \%$ & $20 \%$ \\
\hline & & & \multicolumn{3}{|c|}{ Perendaman 60 menit } \\
\hline 1. & Warna & 1 & 2,5 & 2,5 & 2,5 \\
\hline 2. & Tekstur & 1 & 1,5 & 2,4 & 2,5 \\
\hline \multirow[t]{2}{*}{3.} & Aroma & 1,5 & 3 & 3 & 3 \\
\hline & & & \multicolumn{3}{|c|}{ Perendaman 75 menit } \\
\hline 1. & Warna & 1 & 2,5 & 3,5 & 4 \\
\hline 2. & Tekstur & 1 & 2,5 & 2,7 & 2,5 \\
\hline \multirow[t]{2}{*}{3.} & Aroma & 1,5 & 3 & 3 & 3,5 \\
\hline & & & \multicolumn{3}{|c|}{ Perendaman 90 menit } \\
\hline 1. & Warna & 1 & 3 & 3,5 & 3,5 \\
\hline 2. & Tekstur & 1 & 2,5 & 3 & 3 \\
\hline 3. & Aroma & 1,5 & 2,5 & 4 & 3,5 \\
\hline
\end{tabular}

Keterangan : Nilai 0 atau $>1=$ tidak memenuhi kriteria tahu yang baik

Nilai 2 atau 4 = memenuhi kriteria tahu yang baik

\section{Pembahasan}

\section{Pengaruh Pemberian Kunyit (Curcuma domestica) Terhadap Penurunan Kadar Formalin dan Organoleptik pada Tahu Pengaruh Lama Perendaman}

Kadar formalin pada tahu cenderung mengalami penurunan sedikit setelah perlakuan perendaman larutan kunyit, bisa dilihat pada masing-masing perendaman. Pada perendaman dengan konsentrasi larutan kunyit 10\% mampu menurunkan kadar formalin tahu kontrol yaitu 1,612 ppm, setelah perendaman (60 menit) turun menjadi 1,524 ppm, selama (75 menit) menjadi 1,522 dan selama (90 menit) yaitu 1,517 ppm. Sehingga kadar formalin turun sebesar 5\% pada setiap perlakuan perendaman. Pada perlakuan penyimpanan 24 jam tidak begitu jauh dari hari sebelumnya, yaitu turun sebanyak $7 \%$ pada perendaman 60 menit, pada perendaman 75 menit dan perendaman 90 menit turun sebanyak $8 \%$. Pada perlakuan penyimpanan 48 jam kadar formalin turun sebanyak $11 \%$ pada perendaman 60 , pada perendaman 75 menit dan 90 menit turun sebanyak $12 \%$. Namun pada penyimpanan 72 jam pada konsentrasi kunyit $10 \%$ pada perendaman 90 menit penurunan kadar formalin meningkat menjadi $29 \%$.

Pada konsentrasi larutan kunyit 15\% mampu menurunkan kadar formalin setelah perendaman larutan kunyit selama (60 menit) yaitu 1,092 ppm, selama (75 menit) yaitu 1,086 ppm dan selama (90 menit) yaitu 1,082 ppm. Sehingga kadar formalin turun sebanyak $32 \%$ pada masing-masing perendaman. Penyimpanan 24 jam kemampuan menurunkan kadar formalin setelah perendaman larutan kunyit selama (60 menit) yaitu $0,620 \mathrm{ppm}$, selama (75 menit) yaitu 0,617 dan selama (90 menit) yaitu 0,612 ppm. Berbeda jauh dengan perlakuan sebelum penyimpanan. Sehingga 
kadar formalin berkurang sebanyak $61 \%$ pada perendaman 75 menit dan 90 menit. Selanjutnya pada penyimpanan 48 jam dan 72 jam menunjukan hasil yang signifikan, tidak ada perbedaan.

Pada konsentrasi larutan kunyit 20\% mampu menurunkan kadar formalin setelah perendaman larutan kunyit selama (60 menit) yaitu $0.602 \mathrm{ppm}$, selama (75 menit) yaitu $0,599 \mathrm{ppm}$ dan selama (90 menit) yaitu $0,592 \mathrm{ppm}$. Sehingga kadar formalin yang diturunkan sebanyak $62 \%$ dan begitu juga pada penyimpanan 24 jam, 48 jam, dan 72 jam. Dari hasil penelitian ini, artinya lama perendaman tidak begitu mempengaruhi dalam meminimalisir formalin pada tahu, karena hasil yang didapat berbeda sangat sedikit pada setiap perlakuan perendaman.

\section{Pengaruh Konsentrasi Larutan Kunyit}

Hasil penelitian mengenai pengaruh konsentrasi larutan kunyit dengan berbagai konsentrasi yaitu 0\%, 10\%, 15\%, $20 \%$. Terlihat bahwa pada konsentrasi $0 \%$ atau tanpa perlakuan perendaman kunyit kadar formalin pada tahu hanya mengalami penurunan sedikit selama penyimpanan 72 jam, yaitu dari rata-rata kadar formalin awal sebelum penyimpanan total $1,612 \mathrm{ppm}$ dan setelah penyimpanan 24 jam menjadi 1,567 ppm berkurang sebanyak 3\%, 48 jam penyimpanan menjadi 1,542 ppm berkurang sebanyak $3 \%$, dan setelah penyimpanan 72 jam menjadi 1,562 ppm berkurang sebanyak $2 \%$. Sedangkan setelah pemberian larutan kunyit dengan berbagai konsentrasi (10\%, 15\%, 20\%) kadar formalin pada setiap sampel mengalami penurunan. Penurunan kadar formalin ini berbeda tiap perlakuan konsentrasi.
Pada lama perendaman 60 menit penurunan kadar formalin pada konsentrasi kunyit $10 \%$ dapat menurunkan kadar formalin tahu kontrol yaitu1,612 ppm menurun menjadi 1,524 ppm sehingga kadar formalin turun sebesar $5 \%$ dari konsentrasi awalnya. Pada konsentrasi kunyit $15 \%$ dapat menurunkan kadar formalin tahu kontrol yaitu 1,612 ppm menurun menjadi $1,092 \mathrm{ppm}$ sehingga kadar formalin turun sebesar $32 \%$ dari konsentrasi awalnya. Pada konsentrasi kunyit $20 \%$ dapat menurunkan kadar formalin tahu kontrol yaitu 1,612 ppm menurun menjadi 0,602 ppm sehingga kadar formalin turun sebesar $62 \%$ dari konsentrasi awalnya.

Pada lama perendaman 75 menit penurunan kadar formalin pada konsentrasi kunyit $10 \%$ dapat menurunkan kadar formalin tahu kontrol yaitu1,612 ppm menurun menjadi 1,522 ppm sehingga kadar formalin turun sebesar $6 \%$ dari konsentrasi awalnya. Pada konsentrasi kunyit $15 \%$ dapat menurunkan kadar formalin tahu kontrol yaitu 1,612 ppm menurun menjadi $1,086 \mathrm{ppm}$ sehingga kadar formalin turun sebesar $33 \%$ dari konsentrasi awalnya. Pada konsentrasi kunyit 20\% dapat menurunkan kadar formalin tahu kontrol yaitu 1,612 ppm menurun menjadi $0,599 \mathrm{ppm}$ sehingga kadar formalin turun sebesar $63 \%$ dari konsentrasi awalnya. Begitu juga dengan perendaman selama 90 menit, hasil yang ditunjukan tidak jauh berbeda.

Namun setelah dilakukan penyimpanan 24 jam, penurunan kadar formalin terjadi secara signifikan yaitu pada konsentrasi kunyit 15\% dimana mampu menurunkan kadar formalin tahu kontrol dari 1,567 ppm menjadi 0,620 ppm 
sehingga kadar formalin turun sebesar $61 \%$. Penurunan ini 2 kali lipat dari penurunan kadar formalin sebelum penyimpanan atau setelah perendaman. Begitu juga pada perendaman 75 menit dan 90 menit kadar formalin turun sebesar $61 \%$. Ini dikarenakan kandungan saponin pada kunyit lebih sedikit pada konsentrasi kunyit 15\% dibandingkan konsentrasi kunyit $20 \%$. Pada penyimpanan 48 jam kadar formalin menunjukan penurunan yang signifikan, tidak terdapat perbedaan dalam menurunkan kadar formalin pada masingmasing perendaman.

Pada penyimpanan 72 jam, pada konsentrasi 10\% mampu menurunkan kadar formalin tahu kontrol 1,526 ppm diturunkan menjadi 1,094 ppm sehingga kadar formalin turun sebesar 29\%. Pada perendaman 75 menit dan 90 menit. Artinya pada konsentrasi $10 \%$ lebih efektif saat disimpan selama 72 jam. karena saat disimpan selama 48 jam hanya mampu menurunan kadar formalin sebanyak $6 \%$ sampai $12 \%$.

Dari hasil ini dapat disimpulkan bahwa konsentrasi kunyit 20\% lebih baik dan signifikan dalam mengurangi kadar formalin dari pada konsentrasi kunyit $10 \%$ dan $15 \%$. Sesuai dengan penelitian Wikanta (2011) dalam Jannah (2014) yang menggunakan belimbing wuluh yang mengadung senyawa saponin untuk mereduksi kadar formalin pada udang putih, dijelaskan bahwa kadar residu formalin pada udang putih mengalami penurunan sejalan dengan semakin tingginya konsentrasi belimbing wuluh.

\section{Pengaruh Lama Penyimpanan}

Berdasarkan penelitian yang sudah dilakukan diketahui bahwa lama penyimpanan juga berlaku pada pengurangan kadar formalin pada tahu. Ini terlihat dari kadar formalin pada kontrol positif yang tidak diberi larutan kunyit dimana saat penyimpanan 72 jam kadar formalin 1,612 ppm dan setelah penyimpanan selama 72 jam kadar formalin berkurang sedikit menjadi 1,562 ppm.

Hal ini disebabkan karena larutan formalin yang terserap ke dalam tahu sulit untuk dilepaskan dengan cepat. Selain itu, dipengaruhi oleh penyimpanan suhu dingin sehingga proses penguapan berjalan lambat (Fadhillah, 2013). Hal ini sependapat dengan penelitian Arifin (2007) dalam Fadhillah (2013), menyatakan bahwa daging yang direndam dalam larutan formalin sebagai pengawet, formalin tersebut pada protein serta senyawa lain dan sisanya tetap dalam bentuk formalin bebas kemudian akan diserap ke dalam jaringan (daging), sehingga akan terlindungi dari udara luar dan akibatnya sangat lambat terjadi penguapan.

Setelah diberi perlakuan perendaman larutan kunyit pada masing-masing perlakuan konsentrasi yaitu (10\%, 15\%, $20 \%$ ) kadar formalin mengalami penurunan lebih banyak dibandingkan dengan tahu kontrol. Pada konsentrasi kunyit 10\% mampu menurunkan kadar formalin sebanyak 5\%, konsentrasi kunyit 15\% mampu menurunkan kadar formalin sebanyak 32\% dan konsentrasi kunyit 20\% mampu menurunkan kadar formalin sebanyak $62 \%$. Pada penyimpanan 24 jam konsentrasi kunyit $15 \%$ mampu menurukan kadar formalin sebanyak 61\%, 2 kali lipat lebih banyak dari sebelumnya. Sedangkan konsentrasi kunyit 10\% hanya mampu menurunkan kadar formalin sebanyak $7 \%$ $8 \%$, dan konsentrasi kunyit 20\% tidak 
mengalami peningkatan dari hari sebelumnya yaitu $62 \%$. Begitu juga pada penyimpanan 48 jam, dan 72 jam, perubahan yang terjadi tidak terlalu signifikan, dimana hanya konsentrasi $10 \%$ yang mengalami peningkatan sedikit yaitu pada penyimpanan 48 jam persentase penurunan kadar formalin sebanyak $12 \%$ dan penyimpanan 72 jam turun sebanyak $29 \%$ pada perendaman 75 menit dan 90 menit.

Dari data pengamatan dan hasil analisis secara statistik maka diperoleh hasil bahwa perlakuan lama perendaman tidak berpengaruh nyata terhadap kadar formalin pada tahu yaitu F hitung -0,022 lebih kecil dari $\mathrm{F}$ tabel 6,94. Pada perlakuan dengan penambahan konsentrasi larutan kunyit tidak berpengaruh nyata terhadap kadar formalin pada tahu yaitu F hitung 0,864 lebih kecil dari F tabel 3,16. Perlakuan lama penyimpanan tidak berpengaruh nyata terhadap kadar formalin pada tahu yaitu $\mathrm{F}$ hitung -11,16 lebih kecil dari 2,73 (hal ini terlihat pada tabel 12).

Hasil analisis secara statistik pada (tabel 21) perlakuan interaksi antara perendaman dengan penyimpanan berpengaruh nyata yaitu $\mathrm{F}$ hitung 152,16 lebih besar dari F tabel 2,23. Perlakuan antara perendaman dengan konsentrasi larutan kunyit berpengaruh nyata yaitu $\mathrm{F}$ hitung 303,51 lebih besar dari F tabel 2,01, dan perlakuan interaksi antara perendaman, konsentrasi larutan kunyit dan lama penyimpanan berpengaruh nyata terhadap kadar formalin pada tahu yaitu $\mathrm{F}$ hitung 122, 84 lebih besar dari F tabel 1,75.

\section{Mekanisme Penarikan Formalin Dalam Larutan Kunyit}

Formalin merupakan senyawa aktif yang dapat berikatan dengan bahan makanan seperti protein, lemak dan karbohidrat. Ikatan antara formaldehid dan protein, diantaranya membentuk ikatan silang yang sulit dipecah (Marquie,2001; Haberle et al., 2004; dan Kiernan,2006 dalam Wikanta et.al.,2011). Suntoro (1983), menambahkan bahwa formalin yang berkonsentrasi rendah $(4 \%)$ dapat mengeraskan jaringan. Oleh karena itu dengan memanfaatkan zat aktif yang ada pada kunyit yang mengandung senyawa saponin diharapkan mampu mengurangi kadar formalin yang ada pada tahu.

Mekanisme reduksi kadar formalin pada tahu dengan proses perendaman larutan kunyit dengan konsentrasi $10 \%$, $15 \%, 20 \%$ memiliki cara kerja seperti surfaktan. Keberadaan kedua gugus (non polar dan polar) pada surfaktan dalam senyawa saponin, memiliki kualifikasi untuk dapat membentuk emulsi air dan formalin, sehingga saponin berperan sebagai emulgator. Saponin akan larut dalam air dan membentuk misel.

Misel adalah suatu molekul surfaktan mengandung suatu rantai hidrokarbon panjang plus ujung ion. Bagian hidrokarbon dari molekul surfaktan bersifat hidrofobik dan larut dalam zat-zat non polar, sedangkan ujung ion bersifat hidrofilik dan larut dalam air (Furi, 2012 "dalam" Fadhillah, 2013). Bagian yang berbentuk bulat merupakan kepala yang dapat berikatan dengan air dan formalin (bersifat polar). Sedangkan ekornya bersifat non polar. Formalin yang ada dalam tahu larut dalam larutan kunyit dan terperangkap serta terikat pada bagian kepala misel yang 
bersifat polar sehingga dapat larut dalam air. Menurut Rijai (2006) dalam Fadhillah (2013), surface active agent atau surfaktan adalah suatu senyawa yang telah diketahui dapat menjadi penstabil emulsi. Zat surfaktan memiliki daya pembersih yang lebih baik dibandingkan air saja (Fadhillah, 2013).

\section{Pengaruh Kunyit (Curcuma domestica) \\ Terhadap Organoleptik (tekstur, warna, aroma) pada Tahu}

Berdasarkan hasil uji organoleptik tahu selama penyimpanan dingin $10^{\circ} \mathrm{C}$ terdapat perbedaan yang nyata untuk kedua jenis perlakuan (kontrol dan pemberian larutan kunyit). Kenampakan tahu kontrol selama penyimpanan 72 jam adalah kenampakan dari warna menjadi putih, bersih, pada tekstur tahu kontrol menjadi keras, dan padat tidak mudah hancur, pada aroma sangat menyengat bau formalin, Menurut Permadi (2008) dalam Jannah (2014) produk yang ditambahkan formalin memiliki kenampakan yang lebih menarik, yakni lebih bersih, putih, dan utuh. Selain itu, ditambahkan oleh Nelma (2010) dalam Jannah (2014) bahwa formaldehid juga dipakai untuk reaksi kimia yang bisa membentuk ikatan polimer, dimana salah satu hasilnya adalah menimbulkan warna produk menjadi lebih cerah.

Namun seiring dengan lamanya penyimpanan pada suhu dingin $10^{\circ} \mathrm{C}$, kadar formalin pada tahu kontrol berkurang namun sangat sedikit. Penurunan kadar formalin pada perlakuan tahu kontrol disebabkan oleh sifat formalin yang mudah menguap, namun berjalan lebih lambat dalam suhu dingin (Jannah, 2014).

Sedangkan setelah penambahan larutan kunyit kenampakan organoleptik tahu berubah dibandingkan tahu kontrol. Dimana pada perlakuan konsentrasi kunyit $10 \%$ dengan lama perendaman selama 60 menit warna tahu menjadi kuning, tekstur masih agak keras tapi beda dengan tahu kontrol dan aroma kunyit lemah tidak menyengat. Pada perendaman 75 menit warna menjadi kuning, tekstur sedikit lembut dari tahu kontrol, dan aroma kunyit lemah tidak menyengat. Pada perendaman 90 menit warna menjadi kuning, tekstur sedikit lembut namun selama penyimpanan 72 jam tekstur menjadi semakin lembut, dan aroma kunyit lemah tidak menyengat.

Pada perlakuan konsentrasi kunyit $15 \%$ dengan lama perendaman selama 60 menit warna tahu menjadi kuning dan berubah kuning buram selama penyimpanan 72 jam, tekstur lembut dan aroma kunyit lemah tidak menyengat. Pada perendaman 75 menit warna menjadi sangat kuning, tekstur sedikit lembut dari tahu kontrol, dan aroma kunyit lemah tidak menyengat. Pada perendaman 90 menit warna menjadi sangat kuning, tekstur sedikit lembut namun selama penyimpanan 72 jam tekstur menjadi semakin lembut, dan aroma kunyit kuat menyengat.

Pada perlakuan konsentrasi kunyit $20 \%$ dengan lama perendaman selama 60 menit warna tahu menjadi kuning dan berubah kuning buram selama penyimpanan 72 jam, tekstur lembut dan aroma kunyit lemah tidak menyengat. Pada perendaman 75 menit warna menjadi sangat kuning, tekstur sedikit lembut dari yang awal dan semakin lembut selama penyimpanan $72 \mathrm{jam}$, dan aroma kunyit kuat menyengat dan semakin berkurang selama penyimpanan. Dan pada perendaman 90 menit warna menjadi sangat kuning, tekstur sedikit lembut namun 
selama penyimpanan 72 jam tekstur menjadi semakin lembut, dan aroma kunyit kuat menyengat.

\section{KESIMPULAN}

1. Efektivitas larutan kunyit (Curcuma domestica) dalam mereduksi formalin pada tahu yang paling tepat adalah pada konsentrasi $20 \%$ dengan perendaman selama 90 menit dan penyimpanan selama 72 jam.

2. Semakin lama penyimpanan pada suhu dingin maka warna pada tahu semakin pucat atau tidak cerah, pada tekstur dari yang awalnya hanya sedikit lembut menjadi lembut. Sangat beda dengan tahu kontrol yang keras, ini disebabkan karena semakin berkurangnya kandungan formalin pada tahu sehingga tekstur semakin lembut. Pada aspek aroma, aroma formalin benar-benar menghilang karena tertutupi oleh aroma kunyit.

\section{DAFTAR PUSTAKA}

Arifin, Zainal. 2007. Stabilitas Formalin dalam Daging Ayam Selama Penyimpanan. Bogor : Balai Besar PenelitianVeteriner

Ahmar. 2012. Hakekat Pembelajaran. http://eprints.uny.ac.id/8597/3/Bab20 08 108249131.pdf

Damayanti, E. dkk. 2014. Jurnal Efektivitas Kunyit (Curcuma longa Linn.) Sebagai Pereduksi Formalin Pada Udang Putih (Penaeus merguiensis) Selama $P$ enyimpanan Suhu Dingin. 3(1). Universitas Diponegoro. Semarang

Dewi, K. Y. 20013. Pemanfaatan biji nangka (Artocarpus heterophyllus) sebagai Bahan baku pembuatan es krim dengan pewarna alami Kunyit (Curcuma domestica)

Fadhilah, A. 2013. Efektivitas Lidah Buaya (aloe vera) di dalam Mereduksi Formalin Pada Fillet Ikan Bandeng (chanos chanos forsk) Selama Penyimpanan Suhu Dingin. Volume 2, Nomor 3. Semarang : Universitas Diponegoro

Furi, T. A. 2012. Pengaruh Perbedaan Ukuran Partikel Dari Ampas Tebu Dan Konsentrasi Natrium Bisulfit (Nahso3) Pada Proses Pembuatan Surfaktan. Jurnal Teknik Kimia No. 4, Vol. 18. Palembang : Fakultas Teknik Universitas Sriwijaya

Hastuti, S. 2010. Analisis Kualitatif dan Kuantitatif Formaldehid Pada ikan Asin di Madura. Universitas Trunojoyo. Bangkalan.

Harto, K. 2012. Materi Pendidikan dan Pelatihan Profesi Guru. Palembang: IAIN Raden Fatah Press.

Jannah, M. 2014. Efektivitas Lengkuas (Alpinia galangal) Sebagai Pereduksi Kadar Formalin Pada Udang Putih (Penaeus merguiensis) Selama Penyimpanan Dingin. Vol 3. No 1. Semarang : Universitas Diponegoro Mardiana. 2010. Pengaruh Lama Penyimpanan dan Konsentrasi NAtrium Benzoat Pada Suhu Berbeda Terhadap Kadar Vitamin C CAbai Merah (Capsivum annum L) dan Sumbangsihnya PadaMateri Zat-Zat Makanan Dikelas XI MA/SMA. UIN Raden Fatah. Palembang.

Mustafa, R. M. 2006. Studi Efektivitas Bahan Pengawet Alami Dalam Pengawet Alami. Institut Pertanian Bogor. 
Nurheti. 2007. formalin. Palembang: Artikel

Sihombing, P. A. 2007. Jurnal Aplikasi ekstrak Kunyit (Curcuma domestica) Sebagai Bahan Pengawet Mie Basah. Institut Pertanian Bogor. Bogor.

Sihombing, V. M. 2008. Jurnal Analisa Kadar Zat Pewarna Kuning Pada Tahu Yang Dujial Di Pasar-Pasar Di Medan. Universitas Sumatera Utara. Medan.

Soekarto, Soewarno T. 1985. Penilaian Organoleptik Untuk Industri Pangan dan Hasil Pertanian. Bogor. PUSBANGTEPA/Food Tecnology Development Center, Institut Pertanian Bogor.

Sukardi, I. 2013. Model-Model Pembelajaran Modern Bakal Untuk Guru Profesional. Palembang : Tunas Gemilang Press

Sumarni, B, A. 2014. Pempek Kuliner Khas Palembang. Palembang: Artikel.

Susanti, S. 2010. Jurnal Penetapan Kadar Formaldehid Pada TAhu Yang Dijual Di Pasar Ciputat Dengan Metode Spektrofotometri UV-Vis Disertai
Kolorimetri Menggunakan Pereaksi NASH. 4(2). UIN Syarif Hidayatullah. Jakarta.

Susiwi. 2009. Penilaian Organoleptik. Universitas Pendidikan Indonesia. Jakarta.

Trianto. 2009.Mendesain Model - Model Pembelajaran Inpvatif-Progresif. Jakarta: Pranada Media

Walangare, A. S. Rancang Bangun Alat Konversi Air Laut Menjadi Air Minum Dengan Proses Destilasi Sederhana Menggunakan Pemanas Elektrik Jurusan Teknik Elektro-FT. UNSRAT, Manado.

Widodo, P. B. 2006. Reliabilitas dan Validitas Konstruk Skala Konsep Diri untuk Mahasiswa Indonesia. Jurnal Psikologi Universitas Diponegoro. 3(1) : 1-9.

Yulianusi . 2013. Compounding dispensing Pada Sediaan Farmasi. wordpress.com 